\title{
Pengaruh Bauran Pemasaran dalam Bisnis Konveksi Clothing Karikatur Bali Terhadap Kepuasan dan Loyalitas Konsumen Pada PT. Eka Jaya Makmur Bali
}

\author{
(The Impact of Marketing Mix in Bali Convection Business on Consumer Satisfaction and \\ Loyalty in PT. Eka Jaya Makmur Bali)
}

\author{
Gde Made Oki Pranajaya* Imam Suroso, Bambang Irawan \\ Jurusan Manajemen, Fakultas Ekonomi dan Bisnis, Universitas Jember (UNEJ) \\ Jln. Kalimantan 37, Jember 68121 \\ E-mail: gdemadeokipranajaya@gmail.com
}

\begin{abstract}
Abstrak
Penelitian ini bertujuan untuk mengetahui pengaruh bauran pemasaran dalam bisnis konveksi clothing karikatur Bali terhadap kepuasan dan loyalitas konsumen pada PT. Eka Jaya Makmur Bali. Jenis penelitian adalah explanatory research. Populasi penelitian adalah seluruh wisatawan yang berkunjung dan membeli produk baju di outlet Eka Jaya Makmur Bali yang datang bukan dari agent travel perjalanan. Metode pengambilan sampel dalam penelitian ini dilakukan dengan teknik accidental sampling dan didapatkan jumlah sampel 126 responden. Metode analisis data yang digunakan adalah analisis SEM (Structural Equation Modelling). Hasil penelitian ini adalah bauran pemasaran yang meliputi produk, harga, tempat, dan promosi berpengaruh signifikan terhadap kepuasan konsumen. Hal ini menunjukkan bahwa produk yang dijual sesuai dengan kebutuhan dan keinginan konsumen, harga yang ditawarkan terjangkau oleh konsumen, lokasi tempat pembelian produk sudah strategis, dan kegiatan promosi sudah sesuai dengan harapan konsumen. Bauran pemasaran yang meliputi produk, harga, tempat, dan promosi berpengaruh tidak signifikan terhadap loyalitas konsumen. Hal ini menunjukkan bahwa produk yang dijual, harga yang ditawarkan, tempat yang strategis, dan promosi yang sudah dilakukan tidak dapat menjadikan konsumen loyal pada PT. Eka Jaya Makmur Bali. Kepuasan konsumen berpengaruh signifikan terhadap loyalitas konsumen. Hal ini menunjukkan bahwa konsumen yang loyal dapat dipastikan merasa puas dengan apa yang didapatkannya.
\end{abstract}

Kata Kunci: Kepuasan Konsumen, Loyalitas Konsumen, Bauran Pemasaran, SEM.

\begin{abstract}
This study aims to knowing the influence of marketing mix in Bali convection business on cunsomer satisfaction and loyalty in PT. Eka Jaya Makmur Bali. This study is explanatory research. Population is all tourism who visited and bought clothing product in outlet Eka Jaya Makmur Bali who didn't come from travel agent. The sampling method for this study was doing with accidental sampling technique and it got 126 respondents. Data analysis method is Structural Equation Modelling (SEM). The results of research are marketing mix which included product, price, place, and promotion have affected significantly towards customer's satisfaction. It indicated that selling product same as customer's needs and wants, the giving price is reached by consumers, location of buying product is strategic, and promotion same as consumer's hope. Marketing mix which included product, price, place, and promotion have not affected significantly towards customer's loyalty. It indicated that the selling product, the giving price, strategic location, and completed promotion could not change consumer to become loyalty at PT. Eka Jaya Makmur Bali. Customer's satisfaction have affected significantly towards customer's loyalty. It indicated that loyal customer is always feels satisfy with anything they received.
\end{abstract}

Keywords: Customer's Satisfaction, Customer's Loyalty, Marketing mix, SEM.

\section{Pendahuluan}

Pada era saat ini perkembangan dunia fashion atau model pakaian sangat cepat berubah dan berkembang pesat. Bukan hanya di Eropa tetapi masyarakat di Indonesia juga sangat mengikuti perkembangan fashion atau model baju yang sedang trend di dunia. Ini menimbulkan banyak pengusahapengusaha yang bergerak dan bertahan di produksi konveksi pakaian. Banyak perusahaan konveksi yang memberikan suatu keunikan dalam produksinya agar mempunyai daya saing dan beda dengan yang lainnya. Masyarakat Indonesia adalah salah satu masyarakat yang memiliki pola konsumtif atau suka berbelanja. Banyak orang yang jika berpergian jauh suka berbelanja untuk cindera mata, ini merupakan suatu sasaran bagi para produsen baik perusahaan maupun usaha menengah kecil (UKM) untuk melakukan pemasaran produksi barang cindera mata kepada para konsumen yang datang di tempat-tempat wisata. Salah satu barang yang di sukai oleh wisatawan dan sangat mudah untuk di dapatkan yaitu baju. Setiap daerah selalu memiliki ciri khasnya sendiri dalam desain baju sesuai dengan daerah mereka masingmasing. Di setiap daerah pasti memiliki perusahan industri konveksi masing-masing. Melihat fenomena tersebut para pelaku bisnis konveksi tentu harus menerapkan strategi pemasaran yang menarik serta terus melakukan inovasi agar dapat bertahan dan berkembang, dengan kata lain, industri konveksi yang sudah berjalan maupun pendatang baru, seakan terus dituntut untuk memberikan penawaranpenawaran yang paling menguntungkan bagi konsumen dalam program-program pemasarannya untuk dapat memenangkan persaingan.

\footnotetext{
* Corresponding author
} 
Bisnis konveksi adalah salah satu jenis bisnis yang cukup populer di Indonesia. Tersebar hampir di setiap daerah. Kepopuleran bisnis konveksi utamanya adalah disebabkan karena dua hal. Pertama, karena produk yang dihasilkan oleh industri konveksi, yaitu pakaian merupakan salah satu kebutuhan dasar manusia, maka market untuk bisnis konveksi akan selalu ada. Pangsa pasar yang jelas, membuat tidak sedikit orang yang berusaha memaksimalkan potensi dari bisnis konveksi.

Bisnis konveksi menjadi populer karena entry barrier untuk bisa memulai bisnis ini tidak terlalu besar. Seseorang bisa memulai sebuah bisnis konveksi dengan hanya bermodalkan dua atau tiga buah mesin jahit. Mesin jahit adalah salah satu mesin produksi termurah. Tidak seperti mesin-mesin produksi di industri lainnya yang harganya bisa mencapai ratusan juta atau bahkan milyaran rupiah, seseorang bisa membeli mesin jahit hanya dengan harga ratusan ribu rupiah saja. Seseorang bisa memulai berbisnis konveksi dari garasi rumhanya yang luasnya hanya beberapa meter persegi saja, tidak perlu membuat pabrik yang luasnya ratusan atau ribuan meter persegi.

Fenomena industri konveksi di Bali sangat berkembang pesat karena Bali merupakan merupakan salah satu provinsi di Indonesia yang terkenal di dunia karena wisata dan budaya. Pulau Bali yang menjadi salah satu tempat wisata berkelas internasional selalu mendatangkan investor - investor untuk berbisnis disini. Inilah yang menyebabkan perekonomian di Bali berkembang dan berjalan stabil karena wisatanya yang dapat mendatangkan banyak ke Bali, maka banyak juga pengusaha - pengusaha yang berbisnis seperti bisnis berjualan oleh-oleh khas Bali yang dapat menghasilkan keuntungan.dari wisatawan yang datang ke Bali. Banyak perusahaan yang bergerak di industri konveksi untuk cindera mata.

Bauran Pemasaran atau Marketing Mix merupakan kumpulan dari variabel-variabel pemasaran yang dapat dikendalikan yang digunakan oleh suatu badan usaha untuk mencapai tujuan pemasaran dalam pasar sasaran. menurut Philip Kotler (2005:17), bauran pemasaran atau marketing mix adalah perangkat alat pemasaran taktis yang dapat dikendalikan, produk, harga, distribusi, dan promosi yang dipadukan oleh perusahaan untuk menghasilkan respons yang diinginkan dalam pasar sasaran. Berdasarkan para ahli marketing berpendapat, Marketing mix adalah strategi mengkombinasikan kegiatan-kegiatan marketing, agar tercipta kombinasi maksimal sehingga memunculkan hasil paling memuaskan (Alma, 2005:205). Dalam penelitian yang dilakukan oleh Subagyo (2011) menunjukan terdapat pengaruh positif dan signifikan antara variabel di bauran pemasaran terhadap kepuasan konsumen.

Kepuasan konsumen adalah tingkat perasaan konsumen setelah membandingkan antara apa yang dia terima dan harapannya (Husein Umar, 2005:65). Seorang pelanggan, jika merasa puas dengan nilai yang diberikan oleh produk atau jasa, sangat besar kemungkinannya menjadi pelanggan dalam waktu yang lama.Memuaskan kebutuhan konsumen adalah keinginan setiap perusahaan. Selain faktor penting bagi kelangsungan hidup perusahaan, memuaskan kebutuhan konsumen dapat meningkatkan keunggulan dalam persaingan. Konsumen yang puas terhadap produk dan jasa pelayanan cenderung untuk membeli kembali produk dan menggunakan kembali jasa pada saat kebutuhan yang sama muncul kembali dikemudian hari. Hal ini berarti kepuasan merupakan faktor kunci bagi konsumen dalam melakukan pembelian ulang yang merupakan porsi terbesar dari volume penjualan perusahaan.

Loyalitas pelanggan sangat penting artinya bagi perusahaan yang menjaga kelangsungan usahanya maupun kelangsungan kegiatan usahanya. Pelanggan yang setia adalah mereka yang sangat puas dengan produk dan pelayanan tertentu, sehingga mempunyai antusiasme untuk memperkenalkannya kepada siapapun yang mereka kenal. Selanjutnya pada tahap berikutnya pelanggan yang loyal tersebut akan memperluas "kesetiaan" mereka pada produk-produk lain buatan produsen yang sama. Dan pada akhirnya mereka adalah konsumen yang setia pada produsen atau perusahaan tertentu untuk selamanya. Kotler dan Keller (2007:25) menyatakan bahwa loyalitas tinggi adalah pelanggan yang melakukan pembelian dengan prosentasi makin meningkat pada perusahaan tertentu dari perusahaan lain. Dalam penelitian yang dilakukan oleh Subagyo (2011) menunjukan terdapat pengaruh positif dan signifikan antara variabel di bauran pemasaran terhadap loyalitas konsumen. Persaingan dalam bisnis pakaian oleholeh ini bergerak sangat cepat. Kondisi tersebut berhadapan pula dengan industri sejenis dengan tingkat persaingan yang semakin tajam di pasar domestik, masing-masing industri konveksi berlomba untuk menarik pelanggan dengan mengoptimalkan kualitas produk. karena apabila perusahaan ingin memenangkan persaingan bisnis harus memberikan nilai yang terbaik bagi para pelanggannya. Hal ini juga mendorong terciptanya sebuah strategi bersaing yang tepat agar perusahaan mampu bersaing di tengah-tengah gejolak pasar seperti saat ini.

Salah satu perusahaan industri konveksi yang terkenal di Bali adalah PT. Eka Jaya Makmur adalah perusahaan yang bergerak di bidang konveksi yang memproduksi pakaian karikatur bali yang sudah terkenal. Perusahaan ini bertempat di Kabupaten Badung, dengan kualitas produksinya yang sangat optimal membuat PT. Eka Jaya Makmur yang di miliki oleh Bapak Made Eka ini dapat memproduksi hasil konveksi karikatur Bali yang mampu bersaing di pasar domestik. Perusahaan ini mempunyai keunggulan dan memiliki identitas atau ciri khas sendiri di tahap proses sablon dan desain clothing yang memadukan unsur lokal budaya dan unsur modern. Kelebihan dari produk ini adalah memiliki tema atau karakter dari desain yang sangat kuat, desain dari produknya mengambil tema pemandangan Bali yang di padukan dengan tulisan aksara Bali. Kualitas yang bagus dan pelayanan yang ramah membuat kepuasan sendiri terhadap konsumen dan konsumen dapat loyal terhadap perusahaan ini. PT. Eka Jaya Makmur Bali ini memiliki tiga outlet di Bali, ini juga memudahkan para wisatawan atau konsumen untuk berbelanja di outlet ini. Fenomena perusahaaan industri konveksi di Bali juga banyak, ada beberapa perusahaan besar yaitu Joger pabrik kata-kata Bali, Khrisna, Erlangga, Galuh Art Shop, dll.

Bali merupakan pulau yang selalu mendatangkan wisatawan asing maupun domestik. Hal ini membuat usaha yang bergerak di bidang oleh-oleh khas Bali selalu kebanjiran pelanggan khusunya baju khas Bali. Perusahaan konveksi yang memproduksi baju oleh-oleh khas Bali selalu menjadi target sasaran dari para wisatawan. 
Bauran Pemasaran atau Marketing Mix merupakan kumpulan dari variabel-variabel pemasaran yang dapat dikendalikan yang digunakan oleh suatu badan usaha untuk mencapai tujuan pemasaran dalam pasar sasaran. Sebagaimana yang dinyatakan oleh Philip Kotler (2005:17), Bauran pemasaran atau marketing mix adalah perangkat alat pemasaran taktis yang dapat dikendalikan, produk, harga, distribusi, dan promosi yang dipadukan oleh perusahaan untuk menghasilkan respon yang diinginkan dalam pasar sasaran. Berdasarkan para ahli marketing, Alma (2005:205) berpendapat, Marketing mix adalah strategi mengkombinasikan kegiatan-kegiatan marketing, agar tercipta kombinasi maksimal sehingga memunculkan hasil paling memuaskan.

Hipotesis pada penelitian ini antara lain variabel produk, harga, tempat, dan promosi berpengaruh terhadap kepuasan konsmen PT. Eka Jaya Makmur, variabel produk, harga, tempat, dan promosi berpengaruh terhadap loyalitas konsumen PT. Eka Jaya Makmur, dan kepuasan konsumen berpengaruh terhadap loyalitas konsumen PT. Eka Jaya Makmur.

Berdasarkan latar belakang yang telah diuraikan diatas, maka rumusan masalah dari penelitian ini adalah (1) apakah variabel produk, harga, tempat, dan promosi berpengaruh terhadap kepuasan konsumen PT. Eka Jaya Makmur? (2) Apakah variabel produk, harga, tempat, dan promosi berpengaruh terhadap loyalitas konsumen PT. Eka Jaya Makmur? (3) Apakah kepuasan konsumen berpengaruh terhadap loyalitas konsumen PT. Eka Jaya Makmur?

Penelitian ini bertujuan untuk mengetahui pengaruh bauran pemasaran dalam bisnis konveksi clothing karikatur Bali terhadap kepuasan dan loyalitas konsumen pada PT. Eka Jaya Makmur Bali.

\section{Metode}

\section{Rancangan Penelitian}

Rancangan penelitian ini merupakan penelitian penjelasan (explanatory research), menurut Singarimbun (2010:67) explanatory research bertujuan untuk menjelaskan hubungan-hubungan antara variabel melalui pengujian hipotesis, untuk melaksanakan penelitian tersebut, pengambilan data dilakukan dengan cara penyebaran kuisioner yang datanya dikumpulkan dari sampel atas populasi untuk mewakili seluruh populasi.

\section{Jenis dan Sumber Data}

Jenis data dalam penelitian adalah data kuantitatif yaitu data yang memiliki karakteristik dari suatu variabel yang nilai nilainya dinyatakan dalam bentuk numerical (Sugiyono, 2012:13). Sumber data penelitian ini adalah data primer dan data sekunder. Data primer diperoleh melalui penyebaran kuisoner pada konsumen yang membeli pakaian di outlet Eka Jaya Makmur Bali. Data sekunder penelitian ini diperoleh dari jurnal dan artikel yang berasal dari internet yang terkait dengan bauran pemasaran, kepuasan konsumen, dan loyalitas konsumen.

\section{Populasi dan Sampel}

Populasi penelitian ini adalah seluruh wisatawan yang berkunjung dan membeli produk baju di outlet Eka Jaya Makmur Bali yang datang bukan dari agent travel / perjalanan. Metode pengambilan sampel di lakukan dengan cara Accidental Sampling dengan jumlah sampel ditetapkan sebesar 126 responden.

\section{Metode Analisis Data}

Penelitian ini menggunakan metode analisis SEM (Structural Equation Modelling).

\section{Hasil dan Pembahasan}

\section{Hasil}

\section{Karakteristik Responden}

Tabel 1. Karakteristik Responden Berdasarkan Jenis Kelamin

\begin{tabular}{ccc}
\hline Jenis Kelamin & Frekuensi & Persentase \% \\
\hline Laki-laki & 49 & 38.9 \\
Perempuan & 77 & 61.1 \\
\hline Jumlah & 126 & 100
\end{tabular}

Sumber: data primer diolah, 2017.

Berdasarkan Tabel 1, jumlah sampel pada penelitian ini sejumlah 126 responden dan di ketahui bahwa jumlah responden wanita lebih banyak daripada responden laki-laki yaitu sebanyak 77 responden atau $61.1 \%$ dari total sampel, hal ini dikatakan wajar karena responden perempuan lebih banyak suka belanja dan memilih apa yang mereka inginkan sehingga dapat menghabiskan waktu lama di dalam outlet daripada responden laki-laki. Di lapangan, responden perempuan lebih antusias dalam mengisi kuesioner dan meminta pendapat mengenai baju Eka Jaya Makmur Bali. Responden perempuan lebih banyak menghabiskan waktu di outlet daripada responden laki-laki.

Tabel 2. Karakteristik Responden Berdasarkan Usia

\begin{tabular}{ccc}
\hline Usia & Jumlah & Persentase \% \\
\hline $17-25$ tahun & 15 & 11.9 \\
$26-35$ tahun & 58 & 46.0 \\
$36-45$ tahun & 35 & 27.8 \\
$46-55$ tahun & 6 & 4.8 \\
$>55$ tahun & 12 & 9.5 \\
\hline Jumlah & 126 & 100 \\
\hline
\end{tabular}

Sumber: data primer diolah, 2017.

Berdasarkan Tabel 2, jumlah sampel pada penelitian ini sejumlah 126 responden, Dengan jumlah responden berusia 26-35 tahun mendominasi dalam hal pembelian produk baju sebanyak $46 \%$ yang menandakan responden berusia 26-35 tahun adalah pelanggan yang paling banyak membeli produk baju Eka Jaya Makmur Bali. Orang yang berusia 26-35 tahun adalah orang masih memiliki energi untuk melakukan banyak hal salah satunya adalah berwisata dan berbelanja. Kebanyakan peneliti mendapatkan responden yang berumur 30 tahun dan baru menikah yang sedang berlibur dengan pasangannya.

Tabel 3. Karakteristik Responden Berdasarkan Warga Negara Asalnya

\begin{tabular}{ccc}
\hline Warga Negara & Jumlah & Persentase \% \\
\hline Warga Negara Asing & 24 & 19.0 \\
Warga Negara & 102 & 81.0 \\
Indonesia & & \\
\hline Jumlah & 126 & 100 \\
\hline
\end{tabular}

Sumber: data primer diolah, 2017. 
Berdasarkan Tabel 3, jumlah sampel pada penelitian ini sejumlah 126 responden dan di ketahui bahwa jumlah responden Warga Negara Indonesia lebih banyak daripada responden Warga Negara Asing yaitu sebanyak 102 responden atau $81.0 \%$ dari total sampel, hal ini dikarenakan warga indonesia lebih suka membeli cindera mata dalam bentuk baju dari pada warga negara asing yang lebih suka membeli cindera mata dalam bentuk arsitektur contohnya seperti lukisan, patung, pernak-pernik. Juga jangkauan dalam lokasi, warga negara Indonesia lebih mudah menjangkau untuk pergi ke Bali.

\section{Analisis SEM (Structural Equation Modelling)}

Uji Kesesuaian Model (Goodness of Fit Test)

Tabel 4. Indeks Kesesuaian SEM

\begin{tabular}{cccc}
\hline $\begin{array}{c}\text { Kriteria Fit } \\
\text { Model }\end{array}$ & $\begin{array}{c}\text { Nilai Fit } \\
\text { Model }\end{array}$ & Standar & Keterangan \\
\hline $\begin{array}{c}\text { Diharapkan lebih } \\
\mathrm{X}_{2} \text {-chi- } \\
\text { square }\end{array}$ & 142.122 & $\begin{array}{c}\text { kecil dari } \mathrm{X}^{2} \text { pada } \\
\mathrm{df}=126 \text { yaitu } \\
153.198\end{array}$ & Baik \\
Significance & 0.000 & $\geq 0.05$ & Marginal \\
$\begin{array}{c}\text { Probability } \\
\text { RMSEA }\end{array}$ & 0.196 & $\leq 0.08$ & Marginal \\
GFI & 0.901 & $\geq 0.90$ & Baik \\
AGFI & 0.916 & $\geq 0.90$ & Baik \\
CMIN/DF & 1.797 & $\leq 2$ atau 3 & Baik \\
TLI & 0.976 & $\geq 0.90$ & Baik \\
CFI & 0.969 & $\geq 0.90$ & Baik \\
\hline
\end{tabular}

Sumber: Output Analisis SEM, 2017.

Tabel 4, diketahui bahwa dari delapan kriteria yang digunakan untuk menilai baik atau layak tidaknya suatu model ternyata empat kriteria terpenuhi dan empat kriteria marginal. Dengan demikian dapat dikatakan model dapat diterima, yang berarti ada kesesuaian antara model dengan data.

\section{Uji Kausalitas}

Tabel 5. Hasil Pengujian Kausalitas

\begin{tabular}{ccccc}
\hline Hipotesis & $\begin{array}{c}\text { Koefisien } \\
\text { Jalur }\end{array}$ & CR & Probabilitas & Keterangan \\
\hline $\mathrm{Y} 1 \leftarrow \mathrm{X} 1$ & 0.219 & 2.340 & 0.019 & Signifikan \\
$\mathrm{Y} 1 \leftarrow \mathrm{X} 2$ & 0.195 & 1.985 & 0.043 & Signifikan \\
$\mathrm{Y} 1 \leftarrow \mathrm{X} 3$ & 0.411 & 2.175 & 0.030 & Signifikan \\
$\mathrm{Y} 1 \leftarrow \mathrm{X} 4$ & 0.533 & 4.189 & 0.000 & Signifikan \\
$\mathrm{Y} 2 \leftarrow \mathrm{X} 1$ & -0.186 & -1.088 & 0.277 & Tidak Signifikan \\
$\mathrm{Y} 2 \leftarrow \mathrm{X} 2$ & -0.456 & -1.413 & 0.158 & Tidak Signifikan \\
$\mathrm{Y} 2 \leftarrow \mathrm{X} 3$ & -0.215 & -1.287 & 0.198 & Tidak Signifikan \\
$\mathrm{Y} 2 \leftarrow \mathrm{X} 4$ & -0.514 & -1.345 & 0.179 & Tidak Signifikan \\
$\mathrm{Y} 2 \leftarrow \mathrm{Y} 1$ & 1.376 & 2.045 & 0.041 & Signifikan \\
\hline $\mathrm{Sum}$
\end{tabular}

Sumber: output uji kausalitas SEM, 2017.
Berdasarkan Tabel 5 dapat diketahui hasil pengujian kausalitas untuk pengaruh variabel produk terhadap kepuasan konsumen memiliki koefisien jalur positif sebesar 0.219 dengan C.R sebesar 2.340 dan probabilitas (p) dengan tingkat signifikan 0.05 yaitu sebesar 0.019 yang berarti bahwa produk berpengaruh signifikan terhadap kepuasan konsumen Eka Jaya Makmur Bali. Dengan demikian hipotesis yang menyatakan bahwa variabel produk berpengaruh terhadap kepuasan konsumen terbukti kebenarannya.

Hasil pengujian kausalitas untuk pengaruh variabel harga terhadap kepuasan konsumen memiliki koefisien jalur positif sebesar 0.195 dengan C.R sebesar 1.985 dan probabilitas (p) dengan tingkat signifikan 0.05 yaitu sebesar 0.043 yang berarti bahwa harga berpengaruh signifikan terhadap kepuasan konsumen Eka Jaya Makmur Bali. Dengan demikian hipotesis yang menyatakan bahwa variabel harga berpengaruh terhadap kepuasan konsumen terbukti kebenarannya.

Hasil pengujian kausalitas untuk pengaruh variabel tempat terhadap kepuasan konsumen memiliki koefisien jalur positif sebesar 0.411 dengan C.R sebesar 2.175 dan probabilitas (p) dengan tingkat signifikan 0.05 yaitu sebesar 0.03 yang berarti bahwa tempat berpengaruh signifikan terhadap kepuasan konsumen Eka Jaya Makmur Bali. Dengan demikian hipotesis yang menyatakan bahwa variabel tempat berpengaruh terhadap kepuasan konsumen terbukti kebenarannya.

Hasil pengujian kausalitas untuk pengaruh variabel promosi terhadap kepuasan konsumen memiliki koefisien jalur positif sebesar 0.533 dengan C.R sebesar 4.189 dan probabilitas (p) dengan tingkat signifikan 0.05 yaitu $* * *$ atau standar deviasi mendekati nol yang berarti bahwa promosi berpengaruh signifikan terhadap kepuasan konsumen Eka Jaya Makmur Bali. Dengan demikian hipotesis yang menyatakan bahwa variabel promosi berpengaruh terhadap kepuasan konsumen terbukti kebenarannya.

Hasil pengujian kausalitas untuk pengaruh variabel produk terhadap loyalitas konsumen memiliki koefisien jalur negatif sebesar -0.186 dengan C.R sebesar -1.088 dan probabilitas (p) dengan tingkat signifikan 0.05 yaitu $0.277(>0.05)$ yang berarti bahwa produk tidak berpengaruh signifikan terhadap loyalitas konsumen Eka Jaya Makmur Bali. Dengan demikian hipotesis yang menyatakan bahwa variabel produk berpengaruh terhadap loyalitas konsumen tidak terbukti kebenarannya.

Hasil pengujian kausalitas untuk pengaruh variabel harga terhadap loyalitas konsumen memiliki koefisien jalur negatif sebesar -0.456 dengan C.R sebesar -1.413 dan probabilitas (p) dengan tingkat signifikan 0.05 yaitu $0.158(>0.05)$ yang berarti bahwa harga berpengaruh tidak signifikan terhadap loyalitas konsumen Eka Jaya Makmur Bali. Dengan demikian hipotesis yang menyatakan bahwa variabel harga berpengaruh terhadap loyalitas konsumen tidak terbukti kebenarannya.

Hasil pengujian kausalitas untuk pengaruh variabel tempat terhadap loyalitas konsumen memiliki koefisien jalur negatif sebesar -0.215 dengan C.R sebesar -1.287 dan probabilitas (p) dengan tingkat signifikan 0.05 yaitu $0.198(>0.05)$ yang berarti bahwa tempat berpengaruh tidak signifikan terhadap loyalitas konsumen Eka Jaya Makmur Bali. Dengan demikian 
hipotesis yang menyatakan bahwa variabel tempat berpengaruh terhadap loyalitas konsumen tidak terbukti kebenarannya.

Hasil pengujian kausalitas untuk pengaruh variabel promosi terhadap loyalitas konsumen memiliki koefisien jalur negatif sebesar -0.514 dengan C.R sebesar -1.345 dan probabilitas (p) dengan tingkat signifikan 0.05 yaitu $0.179(>0.05)$ yang berarti bahwa promosi berpengaruh tidak signifikan terhadap loyalitas konsumen Eka Jaya Makmur Bali. Dengan demikian hipotesis yang menyatakan bahwa variabel promosi berpengaruh terhadap loyalitas konsumen tidak terbukti kebenarannya.

Hasil pengujian kausalitas untuk pengaruh variabel kepuasan konsumen terhadap loyalitas konsumen memiliki koefisien jalur positif sebesar 1.376 dengan C.R sebesar 2.045 dan probabilitas (p) dengan tingkat signifikan 0.05 yaitu sebesar 0.041 yang berarti bahwa kepuasan konsumen berpengaruh signifikan terhadap loyaltas konsumen Eka Jaya Makmur Bali. Dengan demikian hipotesis yang menyatakan bahwa variabel kepuasan konsumen berpengaruh terhadap loyalitas konsumen terbukti kebenarannya.

\section{Pembahasan}

Pengaruh Produk Terhadap Kepuasan Konsumen PT. Eka Jaya Makmur Bali

Hasil penelitian menunjukkan bahwa variabel produk $\left(\mathrm{X}_{1}\right)$ yang di ukur dengan tiga indikator yaitu kualitas produk, daya tahan produk, dan desain produk dapat di diterima oleh responden pelanggan Eka Jaya Makmur Bali mempunyai pengaruh positif dan signifikan terhadap kepuasan konsumen Eka Jaya Makmur Bali. Sehingga hipotesis yang menyatakan bahwa produk berpengaruh signifikan terhadap kepuasan konsumen Eka Jaya Makmur Bali dapat diterima. Hal ini berarti produk yang di jual atau yang di pasarkan kepada konsumen sudah baik dan menjadi alasan bahwa konsumen Eka Jaya Makmur Bali merasa puas terhadap produk baju dari perusahaan.

Hasil penelitian ini sependapat dengan teori Handoko (2002:23) Produk dan kualitas produk adalah faktor penentu kepuasan konsumen setelah melakukan pembelian dan pemakaian terhadap suatu produk. Dengan kualitas produk yang baik maka keinginan dan kebutuhan konsumen terhadap suatu produk akan terpenuhi, penelitian ini sesuai dengan teori Kotler \& Armstrong (2008:346) bahwa produk merupakan segala sesuatu yang dapat ditawarkan kepasar untuk mendapatkan perhatian, dibeli, digunakan, atau dikonsumsi yang dapat memuaskan keinginan atau kebutuhan.

\section{Pengaruh Harga Terhadap Kepuasan Konsumen PT. Eka Jaya Makmur Bali}

Hasil penelitian menunjukkan bahwa variabel harga $\left(\mathrm{X}_{2}\right)$ yang di ukur dengan tiga indikator yaitu keterjangkauan harga, kesesuaian harga, dan daya saing harga dapat di diterima oleh responden pelanggan Eka Jaya Makmur Bali mempunyai pengaruh positif dan signifikan terhadap kepuasan konsumen. Sehingga hipotesis yang menyatakan bahwa harga berpengaruh signifikan terhadap kepuasan konsumen Eka Jaya Makmur Bali dapat diterima.
Penelitian ini sejalan dengan penelitian Handoko (2013) yang menjelaskan bahwa harga berpengaruh signifikan terhadap kepuasan konsumen karena berpotensi mempengaruhi persepsi dan harapan konsumen tentang barang atau jasa yang ditawarkan serta pada akhirnya akan mempengaruhi kepuasan konsumen.

\section{Pengaruh Tempat Terhadap Kepuasan Konsumen PT. Eka Jaya Makmur Bali}

Hasil penelitian menunjukkan bahwa variabel tempat $\left(\mathrm{X}_{3}\right)$ yang di ukur dengan tiga indikator yaitu kelancaran akses, jangkauan lokasi, lokasi strategis dapat di diterima oleh responden pelanggan Eka Jaya Makmur Bali mempunyai pengaruh positif dan signifikan terhadap kepuasan konsumen Eka Jaya Makmur Bali. Sehingga hipotesis yang menyatakan bahwa tempat berpengaruh signifikan terhadap kepuasan konsumen Eka Jaya Makmur Bali dapat diterima. Hal ini berarti tempat dimana konsumen membeli produk Eka Jaya Makmur Bali sudah baik dan menjadi alasan bahwa konsumen Eka Jaya Makmur Bali merasa puas terhadap tempat penjualan di outlet Eka Jaya Makmur Bali.

Hasil Penelitian sependapat dengan Subagyo (2011) yang membuktikan bahwa tempat memiliki pengaruh terhadap kepuasan konsumen pada rumah makan lestari Jember. Dengan akses tempat yang terjangkau maka keinginan konsumen untuk datang akan bertambah.

\section{Pengaruh Promosi Terhadap Kepuasan Konsumen PT. Eka Jaya Makmur Bali}

Hasil penelitian menunjukkan bahwa variabel promosi $\left(\mathrm{X}_{4}\right)$ yang di ukur dengan tiga indikator yaitu personal selling, advertising, dan public reaction dapat di diterima oleh responden pelanggan Eka Jaya Makmur Bali mempunyai pengaruh positif dan signifikan terhadap kepuasan konsumen Eka Jaya Makmur Bali. Sehingga hipotesis yang menyatakan bahwa promosi berpengaruh signifikan terhadap kepuasan konsumen Eka Jaya Makmur Bali dapat diterima. Hal ini berarti promosi dimana konsumen mendapatkan informasi tentang produk baju Eka Jaya Makmur Bali sudah baik dan menjadi alasan bahwa konsumen merasa puas terhadap promosi dari Eka Jaya Makmur Bali.

Hasil Penelitian sependapat dengan Subagyo (2011) yang membuktikan bahwa promosi memiliki pengaruh terhadap kepuasan konsumen pada rumah makan lestari Jember. Promosi merupakan strategi perusahaan yang penting untuk meningkatkan tingkat penjualan dan perusahaan produk Eka Jaya Makmur Bali. Dengan melakukan promosi maka minat konsumen untuk berbelanja dan datang ke outlet akan bertambah.

\section{Pengaruh Produk Terhadap Loyalitas Konsumen PT. Eka Jaya Makmur Bali}

Hasil penelitian menunjukkan bahwa variabel produk $\left(\mathrm{X}_{1}\right)$ yang di ukur dengan tiga indikator yaitu kualitas produk, daya tahan produk, dan desain produk dapat di diterima oleh responden pelanggan Eka Jaya Makmur Bali mempunyai pengaruh positif namun tidak signifikan terhadap loyalitas konsumen. Sehingga hipotesis yang menyatakan bahwa produk berpengaruh signifikan terhadap kepuasan konsumen Eka Jaya Makmur Bali tidak dapat diterima. Berdasarkan penelitian Selang (2013) membuktikan bahwa produk 
memiliki pengaruh terhadap loyalitas konsumen pada fresh mart bahu mall Manado karena berpotensi mempengaruhi persepsi dan harapan konsumen tentang barang atau jasa yang ditawarkan serta pada akhirnya akan mempengaruhi loyalitas konsumen. Tetapi hal ini tidak berlaku kepada konsumen Eka Jaya Makmur Bali karena beberapa konsumen masih merasakan produk baju dari Eka Jaya Makmur Bali tidak sesuai dengan selera konsumen. Jadi konsumen tidak mau membeli kembali atau hanya puas sesaat dan tidak ingin loyal terhadap produk Eka Jaya Makmur Bali.

Penelitian ini sejalan dengan penelitian yang dilakukan oleh Kurniawan (2013) yang menunjukkan adanya pengaruh yang tidak signifikan antara variabel produk terhadap loyalitas konsumen pengguna toyota avanza veloz di Manado. Dalam penelitian disimpulkan bahwa konsumen mempertimbangkan untuk loyal karena perusahaan mobil setiap tahunnya selalu meluncurkan produk-produk mobil baru yang lebih berinovasi yang memiliki daya tarik terhadap konsumen.

\section{Pengaruh Harga Terhadap Loyalitas Konsumen PT. Eka Jaya Makmur Bali}

Hasil penelitian menunjukkan bahwa variabel harga $\left(\mathrm{X}_{2}\right)$ yang di ukur dengan tiga indikator yaitu keterjangkauan harga, kesesuaian harga, dan daya saing harga dapat di diterima oleh responden pelanggan Eka Jaya Makmur Bali mempunyai pengaruh positif namun tidak signifikan terhadap loyalitas konsumen. Sehingga hipotesis yang menyatakan bahwa harga berpengaruh signifikan terhadap loyalitas konsumen Eka Jaya Makmur Bali tidak dapat diterima. Berdasarkan penelitian Selang (2013) membuktikan bahwa harga memiliki pengaruh terhadap loyalitas konsumen pada fresh mart bahu mall Manado karena berpotensi mempengaruhi persepsi dan harapan konsumen tentang barang atau jasa yang ditawarkan serta pada akhirnya akan mempengaruhi loyalitas konsumen. Tetapi hal ini tidak berlaku kepada konsumen Eka Jaya Makmur Bali karena beberapa konsumen masih merasakan harga dari produk baju Eka Jaya Makmur Bali tidak sesuai dengan harapan dan keinginan konsumen. Jadi konsumen tidak mau membeli kembali atau hanya puas sesaat dan tidak ingi loyal terhadap produk Eka Jaya Makmur Bali.

Penelitian ini sejalan dengan penelitian yang dilakukan oleh Kurniawan (2013) yang menunjukkan adanya pengaruh yang tidak signifikan antara variabel harga terhadap loyalitas konsumen pengguna toyota avanza veloz di Manado. Di dalam penelitiannya dijelaskan bahwa konsumen mempertimbangkan untuk loyal dengan toyota avanza veloz karena harga mobil di setiap tahunnya berubah. Setiap perusahaan mobil juga memiliki strategi tersendiri dalam menarik konsumen contohnya dalam sistem kredit yaitu uang muka yang mampu menarik konsumen untuk membeli produknya.

\section{Pengaruh Tempat Terhadap Loyalitas Konsumen PT. Eka Jaya Makmur Bali}

Hasil penelitian menunjukkan bahwa variabel tempat $\left(\mathrm{X}_{3}\right)$ yang di ukur dengan tiga indikator yaitu kelancaran akses, jangkauan lokasi, lokasi strategis dapat di diterima oleh responden pelanggan Eka Jaya Makmur Bali mempunyai pengaruh positif namun tidak signifikan terhadap loyalitas konsumen. Sehingga hipotesis yang menyatakan bahwa tempat berpengaruh signifikan terhadap loyalitas konsumen Eka Jaya Makmur Bali tidak dapat diterima. Berdasarkan penelitian Subagyo (2013) membuktikan bahwa tempat memiliki pengaruh terhadap loyalitas konsumen pada Rumah Makan Lestari Jember karena berpotensi mempengaruhi persepsi dan harapan konsumen tentang barang atau jasa yang ditawarkan serta pada akhirnya akan mempengaruhi loyalitas konsumen. Tetapi hal ini tidak berlaku kepada konsumen Eka Jaya Makmur Bali karena beberapa konsumen masih merasakan tempat atau outlet dari produk baju Eka Jaya Makmur Bali tidak sesuai dengan harapan dan keinginan konsumen. Jadi konsumen masih ragu untuk datang kembali ke Eka Jaya Makmur Bali.

Hasil penelitian ini sejalan dengan penelitian Selang (2013) yang menyimpulkan bahwa tempat berpengaruh tidak signifikan terhadap Loyalitas Konsumen pada Fresh Mart Bahu Mall Manado. Dalam penelitiannya menjelaskan bahwa tempat berpengaruh tidak signifikan terhadap loyalitas konsumen karena tidak lancarnya akses menuju Fresh Mart Bahu Mall Manado yang selalu macet pada siang sampai malam hari.

\section{Pengaruh Promosi Terhadap Loyalitas Konsumen PT. Eka Jaya Makmur Bali}

Hasil penelitian menunjukkan bahwa variabel promosi $\left(\mathrm{X}_{4}\right)$ yang di ukur dengan tiga indikator yaitu personal selling, advertising, dan public reaction dapat di diterima oleh responden pelanggan Eka Jaya Makmur Bali mempunyai pengaruh positif namun tidak signifikan terhadap loyalitas konsumen. Sehingga hipotesis yang menyatakan bahwa promosi berpengaruh signifikan terhadap loyalitas konsumen Eka Jaya Makmur Bali tidak dapat diterima. Berdasarkan penelitian Selang (2013) membuktikan bahwa promosi memiliki pengaruh terhadap loyalitas konsumen pada fresh mart bahu mall Manado karena berpotensi mempengaruhi persepsi dan harapan konsumen tentang barang atau jasa yang ditawarkan serta pada akhirnya akan mempengaruhi loyalitas konsumen. Tetapi hal ini tidak berlaku kepada konsumen Eka Jaya Makmur Bali karena beberapa konsumen masih merasakan yang dilakukan oleh Eka Jaya Makmur Bali tidak sesuai dengan harapan dan keinginan konsumen. Jadi konsumen masih ragu terhadap promosi dari Eka Jaya Makmur Bali.

Hasil penelitian ini sejalan dengan penelitian Kurniawan (2013) . Dalam penelitiannya menegaskan bahwa promosi berpengaruh tidak signifikan terhadap loyalitas konsumen pengguna Toyota Avanza Veloz, hasil ini membuktikan bahwa konsumen pengguna Avanza Veloz merasa bahwa manajemen Toyota belum maksimal melaksanakan program Promosi, sehingga konsumen menggunakan mobil Avanza Veloz pencitraan dan kemampuan atau kinerja Avanza Veloz yang unggul yang menjadi pertimbangan utama responden penelitian. Selain karena kebutuhan, juga karena memperhitungkan reputasi dari Toyota.

\section{Pengaruh Kepuasan Konsumen Terhadap Loyalitas Konsumen PT. Eka Jaya Makmur Bali}

Hasil penelitian menunjukan bahwa variabel kepuasan konsumen $\left(\mathrm{Y}_{1}\right)$ dapat di terima oleh konsumen mempunyai pengaruh positif dan signifikan terhadap loyalitas konsumen $\left(\mathrm{Y}_{2}\right)$. Sehingga hipotesis yang menyatakan kepuasan 
konsumen berpengaruh signifikan terhadap loyalitas konsumen dapat diterima. Produk baju yang di pasarkan oleh Eka Jaya Makmur Bali memiliki kualitas yang baik, dapat dilihat dari sebagian besar responden merasa puas dengan beberapa aspek seperti produk, harga, tempat dan promosi dari perusahaan.

Penelitian ini sependapat dengan penelitian sebelumnya dari Gilang (2015) yang membuktikan bahwa kepuasan konsumen memiliki pengaruh terhadap loyalitas konsumen produk LCD TV Samsung. Terdapat beberapa persamaan pada penelitian ini diantaranya kepuasan konsumen akan produk yang di hasilkan perusahaan memberikan dampak yang baik dalam menciptakan konsumen yang loyal terhadap produk khususnya produk baju Eka Jaya Makmur Bali.

\section{Simpulan}

Bauran pemasaran yang meliputi produk, harga, tempat, dan promosi berpengaruh signifikan terhadap kepuasan konsumen. Hal ini menunjukkan bahwa produk yang dijual sesuai dengan kebutuhan dan keinginan konsumen, harga yang ditawarkan terjangkau oleh konsumen, lokasi tempat pembelian produk sudah strategis, dan kegiatan promosi sudah sesuai dengan harapan konsumen. Bauran pemasaran yang meliputi produk, harga, tempat, dan promosi berpengaruh tidak signifikan terhadap loyalitas konsumen. Hal ini menunjukkan bahwa produk yang dijual, harga yang ditawarkan, tempat yang strategis, dan promosi yang sudah dilakukan tidak dapat menjadikan konsumen loyal pada PT. Eka Jaya Makmur Bali. Kepuasan konsumen berpengaruh signifikan terhadap loyalitas konsumen. Hal ini menunjukkan bahwa konsumen yang loyal dapat dipastikan merasa puas dengan apa yang didapatkannya.

\section{Referensi}

Alma, Bucheri. 2005. Manajemen Pemasaran dan Pemasaran Jasa. Cetakan 5. Bandung: CV Alfabeta.

Gilang, Febrianto Ardiyanto. 2015. Pengaruh Kualitas Pelayanan Dan Citra Merek Terhadap Kepuasan Pembelian Dan Kepuasan Konsumen (Studi pada Konsumen Kober Mie Setan jalan Simoang Soekarno Hatta no.1-2 Malang). Jurnal Administrasi Bisnis Vol. 22 No. 1 Mei 2015 Hal 1-7.

Handoko, T. Hani. 2002. Manajemen Personalia dan Sumber Daya Manusia. Yogyakarta : BPFE.

Husein, Umar. 2005. Metode Penelitian. Jakarta: Salemba Empat.

Kotler, Philip. 2005. Manajamen Pemasaran, Jilid 1. Jakarta: PT. Indeks Kelompok Gramedia.

Kotler, Philip dan Gary Armstrong. 2008. Prinsip-prinsip Pemasaran. Edisi 12. Jilid 1. Jakarta: Erlangga.

Kotler, Philip dan Keller, Kevin Lane. 2007. Manajemen Pemasaran, Edisi 13, jilid 1. Jakarta: Airlangga.

Kurniawan. 2013. Pengaruh Bauran Pemasaran terhadap Kepuasan Konsumen Rumah Makan Rawon Nguling Probolinggo. Skripsi. Tidak Dipublikasikan. Jember. Fakultas Ekonomi dan Bisnis Universitas Jember.

Selang, Christian Ade. 2013. Bauran Pemasaran (Marketing Mix) Pengaruhnya Terhadap Loyalitas Konsumen Pada Fresh Mart Bahu Mall Manado. Jurnal EMBA. Vol.1 No.3, Hal. 71-80.

Singarimbun. 2010. Metode Penelitian Bisnis. Jakarta: PT Gramedia Pustaka Utama.

Subagyo, Devi Anita. 2011. Pengaruh Bauran Pemasaran Dalam Bisnis Restoran Terhadap Kepuasan Dan Loyalitas Konsumen Pada Rumah Makan Lestari Jember. Skripsi. Jember: Fakultas Ekonomi dan Bisnis Universitas Jember.

Sugiyono. 2012. Metode Penelitian Kuantitatif kualitatif dan R\&D. Bandung: Alfabeta. 